\title{
Different Cooling Rates for Cryopreservation of Semen in Various Livestock Species: A Review
}

\author{
Jasmer Dalal $^{1 *}$, Ajeet Kumar ${ }^{2}$, Ravi Dutt ${ }^{1}$, Gyan $\operatorname{Singh}^{3}$ and R.K. Chandolia ${ }^{1}$ \\ ${ }^{1}$ Department Veterinary Gynaecology and Obstetrics, LUVAS Hisar, (Haryana), India \\ ${ }^{2}$ Department Veterinary Gynaecology and Obstetrics, GADVASU Ludhiana, (Punjab), India \\ ${ }^{3}$ Teaching Veterinary Clinical Complex, LUVAS Hisar, (Haryana), India \\ *Corresponding author
}

\section{A B S T R A C T}

\begin{tabular}{|l|}
\hline Ke y w o r d s \\
Cooling rates, \\
Critical temperature \\
range, \\
Cryopreservation, \\
Semen
\end{tabular}

\section{Introduction}

It has long been known that cooling bovine, ovine, caprine, swine stallion semen too rapidly between $30^{\circ} \mathrm{C}$ and $0^{\circ} \mathrm{C}$ induces a lethal stress in sperms proportional to cooling rate and temperature range (Watson, 1981). Eight times more cryopreserved sperms are required as compared to fresh sperms to achieve fertilization in vivo (Shannon and Vishwanath, 1995). It is generally accepted that at least $50 \%$ of sperm die during the
Artificial insemination is the most valuable tool for the dissemination of superior germplasm and control of venereal diseases. To accomplish this task, successful and effective cryopreservation of semen is imperative. Semen cryopreservation facilitates its transportation from long distances and use of semen even after the death of sire. However effective cryopreservation of semen of many domestic animals is still not achieved because large proportion of sperms does not survive after freezing and thawing process. During cryopreservation of semen, sperms are damaged if semen is not cooled with optimum cooling rates. The objective of this review is to summarize and compare the work on effects of cooling rates and critical temperature range on post thaw semen quality of different animals. It could be concluded from the present review that optimum freezing protocol for buffalo bull, sheep, pig and stallion is not standardized, so far. However, till to some extent success has been achieved in cattle bulls.

freezing and thawing procedures (Watson, 2000) which is known as cold shock. Fast cooling of semen from 30 to $4^{0} \mathrm{C}$ leads to injuries known as "cold shock" (Gilmore et al., 1998; Watson, 2000). There are large interspecies differences with respect to the sensitivity of spermatozoa to cold shock; for example, ram and boar spermatozoa are very susceptible, whereas human spermatozoa are relatively resistant (Watson, 1981; Holt and North, 1984; De Leeuw et al., 1990; Drobnis et al., 1993). For successful semen 
cryopreservation, the composition of an extender and optimal freeze rate play important roles to minimize extra- and intracellular stresses (Hammerstedt et al., 1990; Curry et al., 1994). During cooling, temperature change induces stress on sperm membranes which causes phase changes in lipids and altered functional state of sperm membranes. Such stresses on the membranes may be continued below $0^{\circ} \mathrm{C}$ since phase changes are not complete at $0^{\circ} \mathrm{C}$. It is well known that a major phase change occurs near $5^{\circ}$ to $-15^{\circ} \mathrm{C}$ (Drobnis et al., 1993) and this may be the prime temperature range for temperature dependent injury. An optimum freeze rate must be slow enough to allow water to leave the cells to prevent intracellular ice crystal formation, and fast enough to avoid severe cell dehydration and the solution effect (Mazur, 1970). Polge (1957) for the first time reported that a critical temperature zone between -15 and $-30^{\circ} \mathrm{C}$ is responsible for exerting most of the damage to spermatozoa and if the cooling rates were not optimal, all the cells might be damaged by $-80^{\circ} \mathrm{C}$. Noileset $a l$. , (1995) observed a temperature-dependent discontinuity of the water permeability of mouse sperm plasma membranes between 4 and $0^{\circ} \mathrm{C}$. These data suggest that a membranephase transition occurs between 4 and $0^{\circ} \mathrm{C}$ in mouse sperm during the freezing process. It is generally recognized that the duration of exposure to such events should be minimized for optimal cell survival implying that the cooling rate should be rapid. However, the cooling rate must be slow enough to allow water to leave the cells by osmosis preventing intracellular ice formation which is lethal. Sperm cells are generally frozen at quite rapid rates in the range $15-60^{\circ} \mathrm{C} / \mathrm{min}$, which have been empirically determined as giving the best survival rates, Watson (2000).

There are two main temperature ranges wherein damage to sperm take place during freezing: the period of supercooling $\left(0^{\circ} \mathrm{C}\right.$ to $\left.5^{\circ} \mathrm{C}\right)$ and the formation of ice crystals $\left(-6^{\circ} \mathrm{C}\right.$ to $-15^{\circ} \mathrm{C}$ ) (Woelders et al., 1997). Further, Mazur (1965) has opined that damage to sperm membranes occurs during the temperature range of $-15^{\circ} \mathrm{C}$ to $-60^{\circ} \mathrm{C}$ during freezing and thawing, which is called as critical temperature range. Various scientists have worked on critical range to improve post thaw motility and viability with contradictory results. Kumar et al., (2003) has defined the critical temperature range between 5 to -50 ${ }^{\circ} \mathrm{C}$, when ice crystal forms and consequently cell dehydration resulting into sperm damage under extreme situations (Table 1 and 2).

\section{Cooling rates for buffalo bull semen}

Buffalo spermatozoa are more susceptible to damages during freezing than cattle spermatozoa (Raizada et al., 1990). These damages can be minimized by optimizing the cooling and freezing rates and using appropriate diluting media (Kumar et al., 1992). Dhamiet al., (1996) compared four cooling protocols using Tris-citric acidfructose-yolk-glycerol extender in Murrah buffalo bull semen $\left(10\right.$ to $5^{\circ} \mathrm{C}$ in 1 -2hours; 30 to $5^{\circ} \mathrm{C}$ in $1-2$ hours) and evaluated post thaw motility at thawing rate of $40^{\circ} \mathrm{C} / \mathrm{min}$. It was observed that post thaw motility was similar (35, 36, 41 and 41\%) under both the conditions. Taleviet al., (1994) studied the slow $\left(28^{\circ} \mathrm{C}\right.$ to $5^{\circ} \mathrm{C}$ in 1 hour) and rapid cooling $\left(28^{\circ} \mathrm{C}\right.$ to $5^{\circ} \mathrm{C}$ in 15 minutes $)$ protocols for buffalo bull semen and no significant differences in post-thaw motility of spermatozoa was observed. Dhami and Sahni (1994) compared different cooling protocols for Murrah buffalo bull semen $\left(30^{\circ} \mathrm{C}\right.$ to $5^{\circ} \mathrm{C}$ in 60 and $120 \mathrm{~min}$ ) and found the later protocol more advantageous and yielded highest fertility rate $(68.1 \%)$ upon insemination. On the other hand, Ramakrishnan and Ariff (1994) did not found any significant difference in post thaw motility by using different cooling rates (room temp to $5^{\circ} \mathrm{C}$ in 45,65 and $90 \mathrm{~min}$ ). Del Sorboet al., (1995) examined two freezing 
protocols for buffalo bull semen; a) In step wise cooling in which the straws were exposed to temperatures of $5^{\circ} \mathrm{C}$ for $4 \mathrm{~min}$, $15^{\circ} \mathrm{C}$ for $7 \mathrm{~min},-80^{\circ} \mathrm{C}$ for $15 \mathrm{~min}$ and $-130^{\circ} \mathrm{C}$ for $15 \mathrm{~min}$ and then plunged into liquid nitrogen; b) In continuous cooling, temperature decreased from $5^{\circ} \mathrm{C}$ to $-30^{\circ} \mathrm{C} @$ $20^{\circ} \mathrm{C} / \mathrm{min}$, from $-30^{\circ} \mathrm{C}$ to $-100^{\circ} \mathrm{C} @ 15^{\circ} \mathrm{C} / \mathrm{min}$, then standing for $5 \mathrm{~min}$ at $-100^{\circ} \mathrm{C}$, before immersion into liquid nitrogen. The post-thaw recovery rates were better for "step-wise" than for continuous cooling method. Sukhato et al., (2001) studied the effects of three cooling rates $\left(10,20\right.$ or $\left.30^{\circ} \mathrm{C} / \mathrm{min}\right)$ from $4{ }^{\circ} \mathrm{C}$ to each of either $-40^{\circ} \mathrm{C},-80^{\circ} \mathrm{C}$ or $-120^{\circ} \mathrm{C}$ before plunging into liquid nitrogen. on post thaw motility and fertility of buffalo bull spermatozoa. It was found that cooling rates of 20 or $30^{\circ} \mathrm{C} / \mathrm{min}$ yielded better progressive post thaw motility and fertility. Bhosrekar et al., (1994) compared the conventional freezing method (over liquid nitrogen in static vapours for $10 \mathrm{~min}$ ) and programmable freezing methods for buffalo bull semen. It was found that freezing @ $17.32^{\circ} \mathrm{C} / \mathrm{min}$ between $4^{\circ} \mathrm{C}$ and $-40^{\circ} \mathrm{C}$ with programmable freezer produced better quality frozen semen than the conventional method of freezing. Rasul (2000) studied the effects of freezing rates on post-thaw viability of buffalo spermatozoa extended in Tris-citric acidbased extender. The freezing rates examined between 4 and $-15^{\circ} \mathrm{C}$ were 3 or $10^{\circ} \mathrm{C} / \mathrm{min}$, whereas the freezing rates investigated between -15 and $-80^{\circ} \mathrm{C}$ were 10,20 or $30^{\circ} \mathrm{C}$ min. It was concluded that the different freezing rates tested gave comparable results in terms of post-thaw spermatozoa viability. Dhami et al., (1992) and Ali (2001) reported that a slow cooling rate $\left(30\right.$ to $5^{\circ} \mathrm{C}$ in $2 \mathrm{hrs}$ ) of diluted bovine semen was necessary for successful freezing with good fertility. Contrary to this, Weidler and Zaugg (1975) and Dhami and Sahni (1994) have suggested that fast pre-freeze cooling $\left(30{ }^{\circ} \mathrm{C}\right.$ to $5^{\circ} \mathrm{C}$ in less than $2 \mathrm{~h}$ ) to freeze buffalo semen without affecting its freezability. Andrabi (2009) outlined the cryogenic procedures for buffalo semen as; cooling from 37 or 39 to $4^{0} \mathrm{C}$ at the rate of $0.2-0.4^{0} \mathrm{C} / \mathrm{min}$, equilibration, at least 2 $\mathrm{h}$ at $4^{0} \mathrm{C}$, freezing of straws approximately 4 $\mathrm{cm}$ above liquid nitrogen for 10-20 min, or by the fast-freezing rates (programmable freezing), and thawing at $45-60^{\circ} \mathrm{C}$ for at least 15 seconds. Previously, Dalal et al., (2016) studied three different programmable namely protocol A (4 to $-10^{\circ} \mathrm{C} @-05{ }^{\circ} \mathrm{C} / \mathrm{min},-10$ to $100^{\circ} \mathrm{C} @-40{ }^{\circ} \mathrm{C} / \mathrm{min}$ and -100 to $-140^{\circ} \mathrm{C} @$ $20 \mathrm{C} / \mathrm{min}$ ), protocol B (4 to $-10^{\circ} \mathrm{C} @-05,-10$ to $-40{ }^{\circ} \mathrm{C} @-60{ }^{\circ} \mathrm{C} / \mathrm{min}-40$ to $-100{ }^{\circ} \mathrm{C} @$ $40^{\circ} \mathrm{C} / \mathrm{min}$ and -100 to $-140^{\circ} \mathrm{C} @-20^{\circ} \mathrm{C} / \mathrm{min}$ and protocol $\mathrm{C}$ (4 to $-12^{\circ} \mathrm{C} @-04-12$ to $60^{\circ} \mathrm{C} @-40^{\circ} \mathrm{C} / \mathrm{min}$ and -60 to $-140^{\circ} \mathrm{C} @$ $50^{\circ} \mathrm{C} / \mathrm{min}$ ). In this study, we used twenty-one ejaculates from three Murrah buffalo bulls (7 ejaculates per bull) and extended semen was frozen according to three different freezing protocols as described above using a biofreezer. Post thaw semen samples were evaluated and the average percentage of individual motility, progressive motility, viability, sperm membrane integrity and total sperm abnormalities was similar $(p>0.05)$ in three protocols freezing protocols. In all three protocols, freezing rates were similar in the critical range. It might be the reason for similar outcome of post-thaw parameters. Recently, in an extensive study conducted by Dalal et al., (2018) with different cooling rates applied in critical temperature zone revealed that best post thaw semen quality was obtained with cooling rate at $-30{ }^{0} \mathrm{C} / \mathrm{min}$, $-40{ }^{0} \mathrm{C} / 50{ }^{0} \mathrm{C} / \mathrm{min}$ and $-50{ }^{0} \mathrm{C} / \mathrm{min}$ in the between $4{ }^{0} \mathrm{C}$ to- $15{ }^{0} \mathrm{C},-15{ }^{0} \mathrm{C}$ to $-60{ }^{0} \mathrm{C}$ and $60{ }^{\circ} \mathrm{C}$ to $-140^{\circ} \mathrm{C}$ respectively.

\section{Cooling rates for cattle bull semen}

Januskauskas et al., (1999) studied the effects of two different cooling rates on post thaw motility of Swedish dairy bull semen. Semen was extended in Triladyl and was cooled 
within $20 \mathrm{~min}$ to $19^{\circ} \mathrm{C}$ to $21^{\circ} \mathrm{C}$ and further cooled to $4^{\circ} \mathrm{C}$ at $4.2^{\circ} \mathrm{C} / \mathrm{min}$ (fast) and at $0.1^{\circ} \mathrm{C} / \mathrm{min}$ (slow) cooling rates and equilibrated at $4^{\circ} \mathrm{C}$ for 4 hours. Further, cooling was done to $-10^{\circ} \mathrm{C}$ at a rate of $4^{\circ} \mathrm{C} / \mathrm{min}$ and from $-10^{\circ} \mathrm{C}$ to $-150^{\circ} \mathrm{C}$ at a rate of $40^{\circ} \mathrm{C} / \mathrm{min}$. No difference was observed in post thaw motility using fast and slow cooling rates.

Woelders (1997) studied the effect of cooling rates between -10 and $-70^{\circ} \mathrm{C}$ in the four freezing protocols $-40,-76,-140$, and $300^{\circ} \mathrm{C} / \mathrm{min}$ on viability of bull sperm and found that cooling rate was found to be between 76 and $140^{\circ} \mathrm{C} / \mathrm{min}$ as optimum. Anzaret al., (2011) studied the effects of three cooling rates between -10 and $-80^{\circ} \mathrm{C}\left(-10^{\circ} \mathrm{C}\right.$, $25^{\circ} \mathrm{C}$, and $-40^{\circ} \mathrm{C} / \mathrm{min}$ ) on post thaw motility of bull spermatozoa and found similar post thaw motility. Rodriguez et al., (1975) studied the effects of cooling rates on survival of beef bull spermatozoa. Straws were cooled from $5^{0} \mathrm{C}$ to $-130^{\circ} \mathrm{C}$ in $3.5 \mathrm{~min}$ (fast cooling), in 20 min (moderate cooling) and in $40 \mathrm{~min}$ (slow cooling). It was found that fast cooling resulted into better post thaw motility as compared to others. Kumar et al., (2003) studied the effects of cooling rate on cryosurvival of bull and ram spermatozoa using biofreezer. Semen was extended at $22^{\circ} \mathrm{C}$ and cooled to $5^{\circ} \mathrm{C}$ in $90 \mathrm{~min}\left(0.2^{\circ} \mathrm{C} / \mathrm{min}\right)$ and from $5^{\circ} \mathrm{C}$ to $-5^{\circ} \mathrm{C} @ 5^{\circ} \mathrm{C} / \mathrm{min}$. From $-5^{\circ} \mathrm{C}$ to $-50^{\circ} \mathrm{C}$, semen was cooled using three cooling rates $\left(1,30\right.$, and $\left.50{ }^{\circ} \mathrm{C} / \mathrm{min}\right)$ and then held for 5 min before plunging into liquid nitrogen. Post thaw motility in bull semen was observed as 27.5, 38.3 and $38.3 \%$ and viability as 49.6 , 50.2 and $50.3 \%$ at $1{ }^{\circ} \mathrm{C} / \mathrm{min}, 30^{\circ} \mathrm{C} / \mathrm{min}$ and $50^{\circ} \mathrm{c} / \mathrm{min}$, respectively. Post-thaw motility in ram semen was observed as 15.8, 15.8 and $25.8 \%$ and viability as $31.2,45.7$ and $34.8 \%$ at $1{ }^{\circ} \mathrm{C} / \mathrm{min}, \quad 30^{\circ} \mathrm{C} / \mathrm{min}$ and $50^{\circ} \mathrm{c} / \mathrm{min}$, respectively. It indicates post thaw motility is highest at $50^{\circ} \mathrm{C} / \mathrm{min}$ and viability is highest at $30^{\circ} \mathrm{C} / \mathrm{min}$. It is worth mentioning that for cattle bull semen currently a freezing rate of $\geq 40^{\circ} \mathrm{C}$ is practiced in general for cryopreservation during the critical temperature zone (Anzar et al., 2002).

\section{Cooling rates for ram semen}

Salamon and Maxwell (1995) reported that in the ram spermatozoa, maximum damage occurs between $-10^{\circ} \mathrm{C}$ and $-25^{\circ} \mathrm{C}$ which is the region of ice crystallization. Post-thaw motility in boar semen was observed as 14.2, 21.3 and $10 \%$ and viability as $36.7,43.2$ and $38 \%$ at $1{ }^{\circ} \mathrm{C} / \mathrm{min}, 30^{\circ} \mathrm{C} / \mathrm{min}$ and $50^{\circ} \mathrm{C} / \mathrm{min}$, respectively. It indicates that post thaw motility and viability is highest at the cooling rate of $30^{\circ} \mathrm{C} / \mathrm{min}$. Byrne et al., (2000) compared the effects of two freezing rates @ $5^{\circ} \mathrm{C} / \mathrm{min}$ (fast) and @ $-0.5^{\circ} \mathrm{C} / \mathrm{min}$. (slow) through critical temperature zone $\left(0^{\circ} \mathrm{C}\right.$ to $25^{\circ} \mathrm{C}$ ) on the fertility of ram spermatozoa in vivo and in vitro.

Semen frozen with fast cooling rate yielded higher cleavage rate (57\% vs. $26 \%$ ) and more blastocyst per oocyte $(28 \%$ vs. $13 \%)$ than the semen with slow cooling rate. Insemination with semen frozen with fast cooling rate resulted in a significantly higher pregnancy rate. So, these observations indicate that the post thaw recovery of sperm depends on species and cooling rates. The optimum sperm freezing rate has been reported amongst distinct species, $-50^{\circ} \mathrm{C}$ to $-100^{\circ} \mathrm{C} / \mathrm{min}$ for bulls (Woelders et al., 1997), $-15{ }^{0} \mathrm{C} / \mathrm{min}$ to $-60{ }^{0} \mathrm{C} / \mathrm{min}$ for ram (Byrne et al., 2000; Anel et al., 2003) and $-30^{\circ} \mathrm{C} / \mathrm{min}$ to $-60^{\circ} \mathrm{C} / \mathrm{min}$ for boars (Fiser and Fairfull,1990).Cooling rate within $\left(5^{\circ} \mathrm{C}\right.$ to $\left.-100^{\circ} \mathrm{C}\right)$ results in less intracellular dehydration, less intracellular solute concentrations and less shrinkage of the cells (Mazur, 1984; Woelders, 1997). The best survival of human spermatozoa is obtained when the cooling rate from room temperature to $4 / 5^{\circ} \mathrm{C}$ is of 0.5 to $1.0^{\circ} \mathrm{C} /$ minute (Henry et al., 1993). 
Table.1 Summary of critical temperature range reported by various authors

\begin{tabular}{|l|l|l|}
\hline S.No & \multicolumn{1}{|c|}{ Authors } & Critical temperature range \\
\hline $\mathbf{1}$ & Drobniset al., (1993) & $5^{\circ} \mathrm{C}$ to $-15^{\circ} \mathrm{C}$ \\
\hline $\mathbf{2}$ & Woelderset al., (1997) & $0^{\circ} \mathrm{C} \mathrm{to}-15^{\circ} \mathrm{C}$ \\
\hline $\mathbf{3}$ & Mazur (1965) & $-15^{\circ} \mathrm{C}$ to $-60^{\circ} \mathrm{C}$ \\
\hline $\mathbf{4}$ & Kumar et al. $(2003)$ & $-5^{\circ} \mathrm{C}$ to $-50^{\circ} \mathrm{C}$ \\
\hline $\mathbf{5}$ & Mazur(1970) & $-10^{\circ} \mathrm{C}$ to $-50^{\circ} \mathrm{C}$ \\
\hline $\mathbf{6}$ & Marshall (1984) & $-5^{\circ} \mathrm{C}$ to $-50^{\circ} \mathrm{C}$ \\
\hline $\mathbf{7}$ & Polge(1957) & $-15^{\circ} \mathrm{C}$ to $-30^{\circ} \mathrm{C}$ \\
\hline
\end{tabular}

Table.2 Summary of optimum cooling rates reported by various authors

\begin{tabular}{|l|l|l|l|}
\hline S.No & Author & Species & Optimum cooling rates \\
\hline $\mathbf{1}$ & Dalal et al.(2018) & $\begin{array}{l}\text { Buffalo } \\
\text { bull }\end{array}$ & $\begin{array}{l}-30^{\circ} \mathrm{C} / \mathrm{min}\left(4{ }^{\circ} \mathrm{C} \text { to }-15^{\circ} \mathrm{C}\right), \\
-50^{\circ} \mathrm{C} / \mathrm{min}\left(-15^{\circ} \mathrm{C} \text { to }-140{ }^{\circ} \mathrm{C}\right)\end{array}$ \\
\hline $\mathbf{1}$ & Woelderset al.(1997) & Bull & $50^{\circ} \mathrm{C} / \mathrm{min}$ to $-100^{\circ} \mathrm{C} / \mathrm{min}$ \\
\hline $\mathbf{2}$ & $\begin{array}{l}\text { Anelet al., (2003); Byrne } \\
\text { et al.(2000) }\end{array}$ & Ram & $-15{ }^{\circ} \mathrm{C} / \mathrm{min}$ to $-60{ }^{\circ} \mathrm{C} / \mathrm{min}$ \\
\hline $\mathbf{3}$ & Fiser and Fairfull, (1990) & Boars & $-30^{\circ} \mathrm{C} / \mathrm{min}$ to $-60^{\circ} \mathrm{C} / \mathrm{min}$ \\
\hline
\end{tabular}

In experiments with the spermatozoa of the bull, ram, stallion and boar it has been found that during slow cooling to $-79^{\circ} \mathrm{C}$, there is a critical temperature range between $-15^{\circ} \mathrm{C}$ and $-25^{\circ} \mathrm{C}$ at which the greatest amount of damage occurs (Polge, 1957).

\section{Cooling rates for boar semen}

Medrano et al., (2002) conducted series of experiments using were set up using 20 ejaculates from 13 boars to investigate the effect of different cooling rates on boar sperm cryosurvival using cryomicroscopy. The cooling protocols were split into two stages: (i) from $+5{ }^{\circ} \mathrm{C}$ to $-5{ }^{\circ} \mathrm{C}$ and (ii) from $-5{ }^{\circ} \mathrm{C}$ to $50{ }^{\circ} \mathrm{C}$. Cooling rates in the range $3{ }^{\circ} \mathrm{C} / \mathrm{min}$ to
$12{ }^{\circ} \mathrm{C} / \mathrm{min}$ did not cause significant damage to the sperm plasma membrane between $+5{ }^{\circ} \mathrm{C}$ and $-5^{\circ} \mathrm{C}$; however, spermatozoa cooled at 24 ${ }^{\circ} \mathrm{C} / \mathrm{min}$ to $-5{ }^{\circ} \mathrm{C}$ were slightly damaged. Cooling rates in the range $15{ }^{\circ} \mathrm{C} / \mathrm{min}$ to 60 ${ }^{\circ} \mathrm{C} / \mathrm{min}$ did not produce differences in sperm cryosurvival during freezing between $-5{ }^{\circ} \mathrm{C}$ and $-50{ }^{\circ} \mathrm{C}$, or after thawing. In addition, cooling rates in the range $3{ }^{\circ} \mathrm{C} / \mathrm{min}$ to 80 degrees $\mathrm{C} / \mathrm{min}$ did not produce significant differences in sperm cryosurvival. However, slow freezing i.e. $3^{\circ} \mathrm{C} / \mathrm{min}$ induced a slight increase in the percentage of plasma membrane-damaged spermatozoa (propidium iodide-positive) at $-50 \quad{ }^{\circ} \mathrm{C}$. Fiser (1990) recommended optimal rate for boar semen is $30^{\circ} \mathrm{C} / \mathrm{min}$ this was specifically tested as one 
of the protocols. All samples were rewarmed at $60^{\circ} \mathrm{C} / \mathrm{min}$.

\section{Cooling rates for stallion semen}

Devireddy et al., (2002) reported that optimization of equine sperm cryopreservation protocols requires an understanding of the water permeability characteristics and volumetric shrinkage response during freezing. They employed cell shape-independent differential scanning calorimeter (DSC) technique was used to measure the volumetric shrinkage during freezing of equine sperm suspensions at cooling rates of $5^{\circ} \mathrm{C} / \mathrm{min}$ and $20^{\circ} \mathrm{C} / \mathrm{min}$ in the presence and absence of cryoprotective agents (CPAs). By fitting a model of water transport to the experimentally obtained DSC volumetric shrinkage data, the best-fit membrane the reference membrane permeability at a reference temperature $T_{R}=$ $273.15 \mathrm{~K}$; and apparent activation energy $(\mathrm{kJ} / \mathrm{mol})$ or the temperature dependence of the cell membrane permeability were determined. On the basis of these parameters and mathematical simulation they concluded that the optimal cooling rate for equine sperm in the absence of any CPA is $29^{\circ} \mathrm{C} / \mathrm{min}$ and is $60^{\circ} \mathrm{C} / \mathrm{min}$ in the Kenney extender with CPAs. In another study, Oldenhof et al., (2017) investigated the interplay between cooling rate and protectant concentration for cryopreservation of stallion sperm. Glycerol (GLY), ethylene glycol (EG), dimethyl formamide (DMF), propylene glycol (PG), and dimethyl sulfoxide (DMSO) were tested as cryoprotective agents (CPAs), using concentrations up to $1500 \mathrm{mM}$ and cooling rates ranging from $5^{\circ} \mathrm{C}$ to $55^{\circ} \mathrm{C} / \mathrm{min}$ through modeling and experimental approach. They found that maximal survival of stallion sperm was obtained using intermediate concentrations (250-500 $\mathrm{mM})$ combined with higher cooling rates $\left(26-53^{\circ} \mathrm{C} / \mathrm{min}\right)$, with GLY being more effective compared with
EG. PG and DMSO appear to be less effective as CPAs for stallion sperm.

\section{Cooling rates for rabbit semen}

Maeda et al., (2012) studied the effect of primary cooling rates on the motility and fertility of frozen-thawed rabbit spermatozoa. Rabbit semen diluted with an egg-yolk acetamide extender was cooled from room temperature to $5^{\circ} \mathrm{C}$ at 4 different rates $(-0.1$, $0.2,-0.4,-0.8^{\circ} \mathrm{C} / \mathrm{min}$ ) and then semen was frozen in liquid nitrogen vapour. After thawing, sperm cooled at $-0.1^{\circ} \mathrm{C} / \mathrm{min}$ showed the highest motility $(40.7 \pm 7.3 \%)$; there were no significant differences between the motilities of the $-0.1,-0.2$, and $-0.4^{\circ} \mathrm{C} / \mathrm{min}$ groups. Niasari-Naslaji et al., (2007) studied effects of cooling rates on semen cryopreservation in Bactrian camel (Camelus bactrianus) using Shotordiluents (Tris based extender, with the osmolality of 330 $\mathrm{mOsm} / \mathrm{kg}$ and $\mathrm{pH}$ of 6.9 , favors the short-term preservation of the Bactrian camel spermatozoa under chilled condition). Extended semen was kept in conical flasks at $37^{\circ} \mathrm{C}$ in water bath and gradually cooled to $4^{\circ} \mathrm{C}$ in 4 hours $\left(0.14{ }^{\circ} \mathrm{C} / \mathrm{min}\right.$ : average slow cooling rate). The other cooling rate was $4^{\circ} \mathrm{C}$ in 1 hour $\left(0.55^{\circ} \mathrm{C} / \mathrm{min}\right.$ : average fast cooling rate). It was observed that fast cooling protocol was better than slow cooling.

In conclusion, each species sperm has different membrane composition in terms of cholesterol, phospholipids and various protein domains which interact differently with environment in which they are suspended therefore have different phase transition temperature. Infect, there are animal to animal variation in sperm membrane composition that depends on nutrition and hormonal milieu in the spermatogenesis environment. So, each species sperm has their own optimum freezing protocol. However, over the globe in routine, liquid nitrogen freezing is being used 
for cryopreservation of various species sperm. We discourage it and recommend the programmable freezing with optimal cooling rates.

\section{References}

Ali, A.H. (2001). Trials for preservation of buffalo semen for maximal viability. M.V.Sc Thesis submitted to Fac. Vet. Med., Beni-Suef, Cairo Univ.

Andrabi, S.M.H. (2009). Factors Affecting the Quality of Cryopreserved Buffalo (Bubalus bubalis) Bull Spermatozoa. Reprod. Dom. Anim., 44: 552-569.

Anel, L., Paz, P.D., Álvarez, M., Chamorro, C.A., Boixo, J.C., Manso, A., González, M., Kaabi, M. and Anel, E. (2003). Field and in vitro assay of three methods for freezing ram semen. Theriogenology. 60: 1293-1308.

Anzar, M., He, L., Buhr, M.M., Kroetsch, T.G. and Pauls, K.P. (2002). Sperm apoptosis in fresh and cryopreserved bull semen detected by flow cytometry and its relationship with fertility. Biol. Reprod., 66: 354-360.

Anzar, M., Kroetsch, T. and Boswall, L. (2011). Cryopreservation of bull semen shipped overnight and its effect on post-thaw sperm motility, plasma membrane integrity, mitochondrial membrane potential and normal acrosomes. Animal Reproduction Science. 126: 23-31.

Bhosrekar, M.R., Mokashi, S.P., Purohit, J.R., Gokhale, S.B. and Mangurkar, B.R. (1994). Effect of glycerolization and deep freezing on the levels and release of enzymes in buffalo semen in relation to initial seminal attributes. In: Proceedings of $4^{\text {th }}$ World Buffalo Cong., Sao Paulo, Brazil. International Buffalo Federation, Roma, Italy, pp. 465-467.

Byrne, G.P., Lonergan, P., Wade, M., Duffy, P., Donovan, A., Hanrahan, J.P. and Boland, M.P. (2000). Effect of freezing rate of ram spermatozoa on subsequent fertility in vivo and in vitro. Anim. Reprod. Sci. 62: 265-275.
Curry, M.R., Millar, J.D. and Watson, P.F. (1994). Calculated optimal cooling rates for ram and human sperm, cryopreservation fails to conform with empirical observations. Biol. Reprod., 51: 1014-1021.

Dalal, J., Kumar, A., Honparkhe, M., Singhal, S. and Singh, N. (2016). Comparison of three programmable freezing protocols for the cryopreservation of buffalo bull semen.Ind. J. Ani. Reprod., 37 (2):54-55.

Dalal. J., Kumar, A., Kumar, P., Honparkhe, M., Malik, V.S., Singhal, S., Kaur, S. and Brar, P.S. (2018). Improvement in cryosurvival of buffalo bull (Bubalus bubalis) sperm by altering freezing rate within critical temperature range. Asian Pacific J. Anim. Reprod.,7 (2) 72-78.

De Leeuw, F.E., Colenbrander, B. and Verkleij, A.J. (1990). The role membrane damage plays in cold shock and freezing injury. Reprod. Domest. Anim. (Suppl) 1:95-104.

Devireddy, R.V., Swanlund, D.J., Olin, T., Vincente, W., Troedsson, M.H.T., Bischof, J.C. and K.P. Roberts. (2002). Cryopreservation of equine sperm: optimal cooling rates in the presence and absence of cryoprotective agents determined using differential scanning calorimetry. Biol. Reprod., 66: 222-231.

Dhami, A.J. and Sahni, K.L. (1994). Effects of various cooling from $30^{\circ} \mathrm{C}$ to $5^{\circ} \mathrm{C}$ equilibration and diluents treatments on freezability, post-thaw thermo-resistance, enzyme leakage and fertility of bubaline spermatozoa. Buffalo J., 2: 147-159.

Dhami, A.J., Sahni, K.L. and Mohan, G. (1992). Effect of various cooling rates (from $30^{\circ} \mathrm{C}$ to $5^{\circ} \mathrm{C}$ ) and thawing temperature on deep freezing of Bos taurus and Bos indicus semen. Theriogenology. 38:565-574

Dhami, A.J., Sahni, K.L., Mohan, G. and Jani, V.R. (1996). Effects of different variables on the freezability, post-thaw longevity and fertility of buffalo spermatozoa in the tropics. Theriogenology. 46: 109-120

Drobnis, E.Z., Crowe, L.M., Berger, T., Anchordoguy, T., Overstreet, J.W. and Crowe, J.H. (1993). Cold shock damage is due to lipid phase transitions in cell membranes: a demonstration using sperm as a model. J. Exp. Zool., 265: 432-437. 
Fiser, PS. (1990). Interactions of cooling velocity, warming velocity and glycerol concentration on the survival of frozenthawed boar sperm. Reprod Domest Anim., (Suppl)1: 123-37.

Fiser, P.S. and Fairfull, R.W. (1990). Combined effect of glycerol concentration and cooling velocity on motility and acrosomal integrity of boar spermatozoa frozen in 0.5-ml straws, Mol. Reprod. Dev. 25: 123-129.

Gilmore, J.A., Liu, J., Peter, A.T. and Critser, J.K. (1998). Determination of plasma membrane characteristics of boar spermatozoa and their relevance to cryopreservation. Biol. Reprod., 58: 2836

Hammerstedt, R.H., Graham, J.K. and Nolan, J.P. (1990). Cryopreservation of mammalian sperm: what we ask them to survive. $J$. Androl., 11: 73-88.

Henry, M.A., Noiles, E.E., Gao, D., Mazur, P. and Critser, J.K. (1993). Cryopreservation of human spermatozoa. IV. The effects of cooling rate and warming rate on the maintenance of motility, plasma membrane integrity, and mitochondrial function. Fertil Steril.,60: 911-8.

Holt, W.V. and North, R.D. (1984). Partially irreversible cold-induced lipid phase transitions in mammalian sperm plasma membrane domains: freeze-fracture study. J. Exp. Zool., 230: 473-483.

Januskauskas, A., Gil, J., Soderquist, L., haard, M.G.M., Haard, M.Ch., Johannisson, A. and Rodriguez, H.M. (1999). Effect of cooling rates on post-thaw sperm motility, membrane integrity, capacitation status and fertility of dairy bull semen used for artificial insemination in Sweden. Theriogenology. 52: 641-656.

Kumar, S., Sahni, K.L. and Mohan, G. (1992). Effect of different levels of glycerol and yolk on freezing and storage of buffalo semen in milk, tris and sodium citrate buffers. Buffalo J. 2: 151-156.

Kumar. S., Millar, J.D. and Watson, P.F. (2003). The effect of cooling rate on the survival of cryopreserved bull, ram, and boar spermatozoa: a comparison of two controlled-rate cooling machines Cryobiology. 46: 246-253

Maeda, T., Liu, E., Nishijima, K., Tanaka, M., Yamaguchi, S., Morimoto, M., Watanabe, T., Fan, J. and Kitajima, S. (2012). Effect of the primary cooling rate on the motility and fertility of frozen-thawed rabbit spermatozoa. World Rabbit Sci.20: 65 70.

Marshall, C.E. (1984). Considerations for cryopreservation of semen. Zoo Biol. 3: 343-356.

Mazur, P. (1965). Causes of injury in frozen and thawed cells. J. Gen. Physiol. 47: 347369.

Mazur, P. (1970). Cryobiology: the freezing of biological systems. Science 168: 939-949.

Mazur, P. (1984). Freezing of living cells: mechanisms and implications. Am. J. Physiol. 247: C125-C142.

Medrano, A.1., Watson, P.F. and Holt W.V. (2002). Importance of cooling rate and animal variability for boar sperm cryopreservation: insights from the cryomicroscope. Reproduction.123(2):315-22.

Niasari-Naslaji, A., Mosaferi, S., Bahmani, N., Gerami, A., Gharahdaghi, A.A., Abarghani, A. and Ghanbari, A. (2007). Semen cryopreservation in Bactrian camel (Camelus bactrianus) using SHOTOR diluent: Effects of cooling rates and glycerol concentrations. Theriogenology. 68:618-625

Noiles, E.E., Bailey, J. and Storey, B.T. (1995). Temperature dependence of the water permeability, Lp, of murine sperm shows a discontinuity between 48 and $08 \mathrm{C}$. Cryobiology. 32:220-238,

Oldenhof, H., Bigalk, J., Hettel, C., De Oliveira Barros, L., Sydykov, B., Bajcsy, A.C., Sieme, H., Wolkers, W.F., (2017). Stallion sperm cryopreservation using various permeating agents: interplay between concentration and cooling rate. Biopreserv. Biobank., 15: 422-431.

Polge, C. (1957). Low temperature storage of mammalian spermatozoa, Proc. Roy. Soc. Lond.147: 488-508.

Raizada, B.C., Sattar, A. and Pandey, M.D. (1990). A comparative study of freezing 
buffalo semen in two dilutors. Proceedings of $2^{\text {nd }}$ World Buffalo Cong, New Delhi, India. International Buffalo Federation, Roma, Italy, pp. 66-74.

Ramakrishnan, P. and Ariff, M.O. (1994). Effect of glycerol level and cooling rate on postthaw semen quality of Malaysian swamp buffalo. Proc. 4th Int. Buffalo Congr., Sao Paulo, Brazil vol. 3 pp. 540-542.

Rasul, Z. (2000). Cryopreservation of buffalo semen. PhD Thesis, submitted to Quaid-iAzam University, Islamabad, Pakistan.

Rodriguez, O.L., Berndtson, W.E., Ennen, B.D. and Pickett, B.W. (1975). Effect of rates of freezing, thawing and level of glycerol on the survival of bovine spermatozoa in straws. J. Anim. Sci. 41:129-136.

Salamon, S. and Maxwell, W.M. (2000). Storage of ram semen. Anim. Reprod. Sci. 62: $77-$ 111.

Salamon, S. and Maxwell, W.M.C. (1995). Frozen storage of ram semen: I. Processing, freezing, thawing and fertility after cervical insemination. Anim. Reprod. Sci.37: 185-249.

Shannon, P. and Vishwanath, R. (1995). The effect of optimal and suboptimal concentrationsof sperm on the fertility of fresh and frozen bovine semen and a theoretical model to explain the fertility differences. Anim. Reprod. Sci.39:1-10.

Sorbo, D., Fasano, C., Fabbrocini, G., Lavadera, A.L. and Sansone, S.G. (1995). Piruvato quale substratoenergetico in extenders crioprotettivi. Effettisull amotilit aallosconge lamento di spermatozo bufalini Bubalusbubalis. Proc. $7^{\text {th }}$ Meeting Nazionale "Studio sullaefficienzariproduttivadeglianimali di interesse zootecnico', Bergamo, Italy vol. 1 pp. 585-588.
Sukhato, P., Thongsodseang, S., Utha, A. and Songsasen, N. (2001). Effects of cooling and warming conditions on post-thawed motility and fertility of cryopreserved buffalo spermatozoa. Anim. Reprod. Sci. 67: 69-77.

Talevi, R., Pelosi, S., Sansone, G., Graso, F. and Matasino, D. (1994). Effect of different prefreezing rates on buffalo sperm motility and ultrastructure preservation. Proceedings of $4^{\text {th }}$ World Buffalo Cong Sao Paulo, Brazil. International Buffalo Federation, Roma, Italy, pp.537-539.

Watson, P.F. (1981). The effects of cold shock on sperm cell membranes. In: Morris $\mathrm{G} \mathrm{J}$, Clarke, A. Eds., Effects of Low Temperatures on Biological Membranes. Academic Press, London. pp. 189-218.

Watson, P.F. (1995). Recent developments and concepts in the cryopreservation of spermatozoa and the assessment of their post-thawing function. Reprod. Fertil. Dev., 7: 871-891.

Watson, P.F. (2000). The causes of reduced fertility with cryopreserved semen. Anim. Reprod. Sci. 60: 481-492.

Weidler, J.F. and Zaugg, N.L. (1975). Fertility of semen in straws unaffected by shortened cooling time to $5^{\circ}$ C. A. I. Digest.23: 9.

Woelders, H. (1997). Fundamentals and recent development in cryopreservation of bull and boar semen. Vet Quart.19: 135- 138.

Woelders, H., Matthijs, A. and Engel, B. (1997). Effects of trehalose and sucrose, osmolality of the freezing medium, and cooling rate on viability and intactness of bull sperm after freezing and thawing. Cryobiology. 35: 93-105.

\section{How to cite this article:}

Jasmer Dalal, Ajeet Kumar, Ravi Dutt, Gyan Singh and Chandolia, R.K. 2018. Different Cooling Rates for Cryopreservation of Semen in Various Livestock Species: A Review. Int.J.Curr.Microbiol.App.Sci. 7(08): 1903-1911. doi: https://doi.org/10.20546/ijcmas.2018.708.219 